\title{
Islands of Neuropil-Like Matrix Present
}

National Cancer Institute

\section{Source}

National Cancer Institute. Islands of Neuropil-Like Matrix Present. NCI Thesaurus. Code C92551.

A morphologic finding indicating the presence of foci of neuropil-like matrix that are immunostained positive for synaptophysin in infiltrating astrocytomas. 